\section{Improving In Vitro Plant Regeneration from Leaf and Petiole Explants of 'Marion' Blackberry}

\author{
Rengong Meng ${ }^{1}$ \\ United States Department of Agriculture, Agricultural Research Service, \\ Horticultural Crops Research Laboratory, Corvallis, OR 97330
}

Tony H.H. Chen ${ }^{2}$

Department of Horticulture, Oregon State University, Corvallis, OR 97331

Chad E. Finn ${ }^{3}$

United States Department of Agriculture, Agricultural Research Service, Horticultural Crops Research Laboratory, Corvallis, OR 97330

Yonghai Li ${ }^{1}$

Department of Statistics, Oregon State University, Corvallis, OR 97331

Additional index words. Rubus, tissue culture, thidiazuron

\begin{abstract}
Experiments focusing on plant growth regulators' concentrations and combinations, mineral salt formulations, and TDZ pretreatment formations were conducted to optimize in vitro shoot regeneration from leaf and petiole explants of 'Marion' blackberry. Optimum shoot formation was obtained when stock plants were incubated in TDZ pretreatment medium for 3 weeks before culturing leaf explants on regeneration medium (Woody Plant Medium with $5 \mu \mathrm{M} \mathrm{BA}$ and $0.5 \mu \mathrm{M}$ IBA) in darkness for 1 week before transfer to light photoperiod (16-hour photoperiod at photosynthetic photon flux of $\approx 50 \mu \mathrm{mol} \cdot \mathrm{m}^{-2} \cdot \mathrm{s}^{-1}$ ) at $23{ }^{\circ} \mathrm{C} \pm 2{ }^{\circ} \mathrm{C}$ for 4 weeks. Under these conditions, $\approx 70 \%$ of leaf explants formed $\approx \mathbf{4 0}$ shoots per petri dish that could be harvested and rooted to form plantlets. Chemical names used: $\mathrm{N}^{6}$-benzyladenine (BA); 2,4-dichlorophenoxyacetic acid (2,4-D); gibberellic acid (GA); indole-3-acetic acid (IAA); indole-3-butyric acid (IBA); $\alpha$-naphthaleneacetic acid (NAA); N-phenyl-N'-1,2,3-thidiazol-5-ylurea [thidiazuron (TDZ)].
\end{abstract}

'Marion' blackberry (Rubus sp. L.) is a hexaploid cultivar derived from a cross between 'Chehalem' and 'Olallie'. It was released in 1956 by the cooperative breeding program of the U.S. Dept. of Agriculture-Agricultural Research Service (USDA-ARS) and the Oregon Agricultural Experiment Station (Finn et al., 1997). It is the most widely planted blackberry cultivar in the world and is the predominant cultivar grown primarily in Oregon's Willamette Valley (Strik, 1992). 'Marion' has become the dominant blackberry with worldwide appeal because of its processing quality including superior texture, color, and flavor. However, the lack of sufficient cold tolerance seriously affects its yield and may lead to an erratic supply from year to year (Bell et al., 1992; Bell and Strik, 1995; Cortell and Strik, 1997). One way to improve 'Marion'

Received for publication 21 Mar. 2002. Accepted for publication 16 Apr. 2003. This work was supported by grants from USDA-ARS Northwest Center for Small Fruit Research grant program and Oregon Caneberry Commission. We thank M. Compton for his critic reading of the manuscript and help in statistical suggestions. We also thank Barbara M. Reed, Patrick P. Moore, and Robert R. Martin for their helpful reviews.

${ }^{1}$ Graduate Research Assistant.

${ }^{2}$ Professor.

${ }^{3}$ Research Geneticist. To whom reprint requests should be sent. E-mail: finnc@science.oregonstate. edu

blackberry's cold hardiness is through the introduction of hardiness genes by traditional breeding. However, this is a slow process and may result in the loss of many of the favorable traits that make up this elite cultivar.

Incorporating cold tolerance genes through recombinant DNA technology is a viable alternative to the use of traditional breeding techniques. Improvement of freezing tolerance traits by genetic engineering was recently demonstrated for Arabidopsis thaliana (L.) Hey Reynh (Jaglo-Ottosen et al., 1998; Kasuga et al., 1999; Sakamoto et al., 2000). In these cases, genes that confer freezing tolerance were introduced without disrupting the otherwise desirable genetic constitutions. This might be an ideal approach to improve cold hardiness of 'Marion' while maintaining favorable processing characteristics. A prerequisite to achieving successful genetic transformation in 'Marion' is the development of an efficient regeneration system that facilitates the regeneration of whole plants from cultured cells, tissues, or organs. Such a system is currently not available for 'Marion' blackberry.

Protocols for in vitro plant regeneration from a number of Rubus genotypes, including blackberries, raspberries ( $R$. idaeus L.), and their hybrids, are available (Cousineau and Donelly, 1991; Fiola and Swartz, 1986; Graham and McNicol, 1990; Mathews et al., 1995; Mezzetti et al., 1997; McNicol and Graham, 1990; Swartz et al., 1990; Tsao, 1999; Turk et al., 1994). In these studies, shoot regeneration competence varied widely among genotypes dictating that experiments be conducted to develop an optimized protocol for individual genotypes. Factors studied include plant growth regulator compositions (type and concentration), medium salt formulation, special treatment of explant (chemical or physical), explant types (leaf, stem), incubation conditions (time, light intensity, and temperature), gelling agent and firmness, age of source plant, and explant orientation during regeneration. Among these studies, only one reported in vitro plant regeneration of 'Marion' (Tsao, 1999). In that study, Tsao (1999) obtained $\approx 40 \%$ plant regeneration from whole leaf explants. However, the number of shoots obtained from responding explant per vessel was not reported. As a highly efficient regeneration method is one of the most important factors in determining the success of a genetic transformation protocol, the major objective of this study was to establish an efficient in vitro shoot regeneration system for 'Marion' blackberry.

\section{Materials and Methods}

Tissue culture maintenance and explant preparation. In vitro cultures of 'Marion' were multiplied and maintained on a Modified Blackberry Multiplication Medium (MBMM, Reed, 1990), which consists of Murashige and Skoog (MS) salts and vitamins (Murashige and Skoog, 1962), 1× MS iron plus $0.2 \mathrm{~g} \cdot \mathrm{L}^{-1}$ of Sequestrene Fe 138 (Novartis, Greensboro, N.C.) with $4.4 \mu \mathrm{M} \mathrm{BA}, 0.5 \mu \mathrm{M}$ IBA and 2.9 $\mu \mathrm{M} \mathrm{GA}_{3}$. Two- to three-month old in vitro micropropagated stock plants were cut into stem segments, each with one to two leaf buds and the leaf blades removed. Stock plants and stem segments were cultured in GA7 Magenta vessels (Magenta Corp., Chicago), each with $40 \mathrm{~mL}$ MBMM or thidiazuron (TDZ) pretreatment medium (MBMM with $1 \mu \mathrm{M}$ TDZ), respectively.

General culture methods and experimental design. Unless otherwise described, healthy and fully expanded leaves and petioles collected from 3-week-old plantlets initiated on TDZ pretreatment medium were used for all experiments. Hyperhydric leaves were discarded. Petioles were excised and the distal 1/3 to $1 / 4$ of leaves were cut transversely through the mid-vein and placed on medium abaxial side down. For petiole explants, petioles were cut into 5-mm segments and placed abaxial side on the surface of regeneration medium. Newly cut explants on regeneration medium were incubated in darkness at $23{ }^{\circ} \mathrm{C} \pm 2{ }^{\circ} \mathrm{C}$ for 1 week before transfer to 16 -h photoperiod [photosynthethic photon flux $(P P F) \approx 50$ $\left.\mu \mathrm{mol} \cdot \mathrm{m}^{-2} \cdot \mathrm{s}^{-1}\right]$ at $23^{\circ} \mathrm{C} \pm 2{ }^{\circ} \mathrm{C}$ for 4 weeks. Each treatment consisted of four replicate plastic petri dishes $(100 \times 15 \mathrm{~mm})$ containing $25 \mathrm{~mL}$ of Woody Plant Medium [WPM (Lloyd and McCown, 1980)] and 12 explants. Replicate dishes were arranged in a completely randomized design with subsampling. All experiments were conducted three times. Data collected in all experiments included the number of regenerating explants and number of shoots 
per petri dish.

Data collection and statistical analysis. Percent regeneration was defined as the percentage of explants that produced at least one shoot. Mean number of shoots per plate was obtained by counting the total number of shoots from regenerating explants in a plate. We recorded percent regeneration and number of shoots/explant weekly from 1 to 4 weeks after the plates were placed in light. However, we only reported the data from the fourth week because differences among treatments were greatest. Statistical analysis was conducted using the Logistic Regression Procedure for the regeneration efficiency (\%) and the Poisson Procedure for number of shoots per petri dish of SAS Version 8.02 (SAS Inst. Cary, N.C., 1999). Regression analysis was used to determine the dosage effect of BA and IBA levels on each explant and time effect of TDZ pretreatment.

Effect of BA and IBA combinations on shoot organogenesis. Thirty factorial combinations of BA $(0,1,2,5$, and $10 \mu \mathrm{M})$ and IBA $(0,0.5,1,2,5$, and $10 \mu \mathrm{M})$ were tested for their effect on shoot regeneration. Leaf and petiole explants were prepared and cultivated as stated above.

Effect of cytokinin type on shoot organogenesis. Using the best BA/IBAconcentrations from the experiment described above, we compared the effect of equal molar concentration of BA, kinetin, and zeatin on shoot regeneration. Leaf explants were placed abaxial side down on WPM with $5 \mu \mathrm{M}$ of individual cytokinin and $0.5 \mu \mathrm{M}$ IBA.

Effect of auxin type on shootorganogenesis. Using the best result from the cytokinin experiments, we compared the effect of equal molar concentration $(0.5 \mu \mathrm{M})$ of IBA, IAA, NAA, and
2,4-D, combined with the best cytokinin and its concentration on shoot regeneration. Leaf explants were prepared as described above.

Effect of medium type on shoot organogenesis. Once the best plant growth regulator and concentrations were known, the effect of three medium formulations WPM, MS, and BMM (Blackberry Multiplication Medium) on shoot organogenesis was compared. Leaf explants were prepared as described above.

Effect of TDZ pretreatment duration on shoot regeneration. We compared the effect of $0,3,4,5$, and 6 weeks of culture on TDZ (1 $\mu \mathrm{M})$ containing medium on shoot regeneration, using the optimum conditions identified in the previous experiments. Leaf explants were prepared and placed on WPM with $5 \mu \mathrm{M} \mathrm{BA}$ and $0.5 \mu \mathrm{M}$ IBA.

Effect of leaf integrity on shoot organogenesis. Shoot regeneration efficiency from entire leaves, the basal $2 / 3$ to $3 / 4$ and the upper $1 / 3$ to $1 / 4$ of the leaf blade was compared. Leaf explants collected from TDZ pretreated plantlets were placed on WPM with $5 \mu \mathrm{M} \mathrm{BA}$ and $0.5 \mu \mathrm{M}$ IBA.

Effect of leaf explant orientation on shoot organogenesis. The top 1/3 to 1/4 of each leaf, collected from TDZ pretreated plantlet, was cut transversely through the mid-vein and placed on WPM with $5 \mu \mathrm{M}$ BA and $0.5 \mu \mathrm{M}$ IBA with either abaxial or adaxial surface in contact with medium.

Effect of wounding on shootorganogenesis. Leaf explants collected from TDZ pretreated plantlets were either wounded with a sharp point dissecting needle or transferred intact to WPM with $5 \mu \mathrm{M} \mathrm{BA}$ and $0.5 \mu \mathrm{M}$ IBA with the abaxial surface in contact with medium. About $1 / 3$ to $1 / 4$ of wounded leaves was cut transversely through the mid-vein and then stabbed $\approx 10$ times with a needle.

\section{Results and Discussion}

Our goal was to develop an efficient plant regeneration system for 'Marion' blackberry in which shoots are directly regenerated from leaf and petiole explants with minimal callusing to minimize the potential of somaclonal variation. Generally, shoots appeared on the explant surface within $10 \mathrm{~d}$ of transfer to light. Examination using a dissecting microscope revealed that shoots originated directly from explants without visible callus.

The number of shoots from regenerating explants peaked at around the third week and then only increased in size but not number (data not shown).

Explant type, BA and IBA combinations on shoot organogenesis. A significant interraction between explant type, BA, and IBA was observed for shoot regeneration rate and number of shoots per petri dish (Table 1 , Table 2). Leaf explants failed to regenerate when IBA increased to 5 and $10 \mu \mathrm{M}$ (Fig. 1A) regardless of BA concentration. At such IBA levels, a low shoot regeneration rate was obtained from petioles only when IBA $5 \mu \mathrm{M}$ was combined with BA $2 \mu \mathrm{M}$ (Fig. 1B). Since explants responded differently to $\mathrm{BA}$ and IBA (Tables 1 and 2), dosage effect of BA and IBA was analyzed using polynomial regression for leaves and petioles separately [Regeneration efficiency $(\%)_{\text {leaf }}=13.21+12.26 * \mathrm{BA}$ $-16.29 * \mathrm{IBA}-0.93 * \mathrm{BA}^{2}-1.83 * \mathrm{BA}^{*} \mathrm{IBA}+$ $3.56 * \mathrm{IBA}^{2}+0.17 * \mathrm{BA}^{2 *} \mathrm{IBA}-0.20 * \mathrm{IBA}^{3}\left(R^{2}\right.$ $=0.65, P<0.0001)$; Regeneration efficiency $(\%)=27.13-16.42 * \mathrm{IBA}-0.51 * \mathrm{BP}^{*} \mathrm{IBA}$ $+0.38 * \mathrm{IBA}^{2}+0.04 * \mathrm{BA}^{*} \mathrm{IBA}^{2}-0.2 * \mathrm{IBA}^{3}$ $\left(R^{2}=0.65, P<0.0001\right) ; \log$ (No. shoots/
Table 1. Logistic procedure (forward selection) summary table for the percentage of explants that produced shoots from 3-week old TDZ pretreated 'Marion' leaf and petiole explants on WPM supplemented with BA and IBA in a $2 \times 5 \times 6$ factorial experiment. Whole experiment was conducted three times. Nonsignificant effects were rejected by forward selection.

\begin{tabular}{|c|c|c|c|c|c|c|}
\hline & \multicolumn{5}{|c|}{ Logistic procedure statistics } \\
\hline & & \multicolumn{2}{|c|}{ Score $\chi^{2}$} & \multirow{2}{*}{$\begin{array}{c}\text { DF } \\
6\end{array}$} & \multicolumn{2}{|c|}{$\operatorname{Pr}>\chi^{2}$} \\
\hline \multicolumn{2}{|c|}{ Likelihood ratio } & \multicolumn{2}{|l|}{977.1} & & \multicolumn{2}{|c|}{$<0.0001$} \\
\hline \multicolumn{7}{|c|}{ Effect entered } \\
\hline Explant & & \multicolumn{2}{|l|}{7.2} & 1 & \multicolumn{2}{|c|}{0.0071} \\
\hline BA & & \multicolumn{2}{|c|}{22.01} & 1 & \multicolumn{2}{|c|}{$<0.0001$} \\
\hline IBA & & \multicolumn{2}{|l|}{818.1} & 1 & \multicolumn{2}{|c|}{$<0.0001$} \\
\hline Explant*B & & \multicolumn{2}{|l|}{20.0} & 1 & \multicolumn{2}{|c|}{$<0.0001$} \\
\hline Explant*IB & & \multirow{2}{*}{\multicolumn{2}{|c|}{$\begin{array}{l}4.0 \\
6.0\end{array}$}} & 1 & \multirow{2}{*}{\multicolumn{2}{|c|}{0.0447}} \\
\hline BA*IBA & & & & 1 & & \\
\hline \multirow[t]{3}{*}{ Residual } & & 2.8 & & 9 & & 9707 \\
\hline & \multicolumn{6}{|c|}{ Maximum likelihood estimates } \\
\hline & DF & Estimate & SE & & Vald $\chi^{2}$ & $\operatorname{Pr}>\chi^{2}$ \\
\hline Intercept & 1 & -1.72 & 0.41 & & 17.46 & $<0.0001$ \\
\hline Explant & 1 & 0.71 & 0.23 & & 9.05 & 0.0026 \\
\hline BA & 1 & 0.61 & 0.10 & & 37.18 & $<0.0001$ \\
\hline IBA & 1 & -0.84 & 0.13 & & 40.07 & $<0.0001$ \\
\hline Explant*BA & 1 & -0.25 & 0.06 & & 19.28 & $<0.0001$ \\
\hline Explant*IBA & 1 & 0.13 & 0.06 & & 4.02 & 0.0450 \\
\hline $\mathrm{BA} * \mathrm{IBA}$ & 1 & -0.05 & 0.02 & & 4.68 & 0.0306 \\
\hline
\end{tabular}

Table 2. Poisson regression summary table for the number of shoots per petri dish from 3-week old TDZ pretreated 'Marion' leaf and petiole explants on WPM supplemented with BA and IBA in a $2 \times 5 \times 6$ factorial experiment. Whole experiment was conducted three times.

\begin{tabular}{l}
\hline Model equation (nonsignificant parameters not included) \\
\hline LOG $($ No. shoots/petri dish) $=$ \\
$0.77+0.69 * \mathrm{BA}-0.48 * \mathrm{IBA}+0.47 *$ Explant $-0.07 * \mathrm{BA}^{2}-0.58 * \mathrm{IBA} *$ Explant
\end{tabular}

Summary of Fit

Mean of Response: 3.1361 Deviance:1621.0295 Pearson $\chi^{2}: 1955.748$

SCALE (Pearson): 1.6679 Deviance/DF: 2.3059 Pearson $\chi^{2} / \mathrm{DF}: 2.7820$

\begin{tabular}{|c|c|c|c|}
\hline \multirow[b]{2}{*}{ Source } & \multicolumn{3}{|c|}{ Analysis of Deviance } \\
\hline & DF & Deviance & Deviance/DF \\
\hline Model & 16 & 3895.4214 & 243.4638 \\
\hline Error & 703 & 1621.0295 & 2.3059 \\
\hline \multirow[t]{2}{*}{ Corrected Total } & 719 & 5516.4509 & --- \\
\hline & \multicolumn{3}{|c|}{ Type III (Wald) Tests } \\
\hline Source & DF & $\chi^{2}$ & $\operatorname{Pr}>\chi^{2}$ \\
\hline BA & 1 & 308.3009 & $<0.0001$ \\
\hline IBA & 1 & 28.4415 & $<0.0001$ \\
\hline Run & 2 & 0.8085 & 0.6675 \\
\hline Explant & 1 & 13.4922 & 0.0002 \\
\hline $\mathrm{BA}^{2}$ & 1 & 314.1789 & $<0.0001$ \\
\hline BA*IBA & 1 & 3.6827 & 0.0550 \\
\hline BA*Run & 2 & 0.4908 & 0.7824 \\
\hline BA*Explant & 1 & 3.7991 & 0.0513 \\
\hline $\mathrm{IBA}^{2}$ & 1 & 1.0194 & 0.3127 \\
\hline IBA*Run & 2 & 0.0884 & 0.9567 \\
\hline IBA*Explant & 1 & 19.9973 & $<0.0001$ \\
\hline Run*Explant & 2 & 2.6307 & 0.2684 \\
\hline
\end{tabular}


petri dish $)_{\text {leaf }}=1.24+0.69 * \mathrm{BA}-0.21 * \mathrm{IBA}$ $-0.07 * \mathrm{BA}^{2} ; \log$ (No. shoots/petri dish) $\left.=0.77+0.69 * \mathrm{BA}-0.48 * \mathrm{IBA}_{-}-0.07 * \mathrm{BA}^{2}\right]$. Among the BA and IBA combinations tested, leaf explants incubated in WPM with $5 \mu \mathrm{M} \mathrm{BA}$ and $0.5 \mu \mathrm{M}$ IBA produced more regenerating leaf explants and shoots per petri dish than any other combinations (Fig. 1, A and B). For petiole explants, we found that no single plant growth regulator alone stimulated high frequency shoot regeneration or a large number of shoots per petri dish (Fig. 1, C and D). Tsao (1999) reported that 5 or $10 \mu \mathrm{M}$ BA combined with zero or $0.5 \mu \mathrm{MIBA}$ was best for stimulating regeneration of 'Marion' leaf explants. Plant regeneration percentage and the number of shoots per petri dish were significantly higher from leaves (Fig. 1, A and B) than petioles (Fig. 1, $\mathrm{C}$ and D). Explants on WPM with 5 or $10 \mu \mathrm{M}$ IBA combined with any concentration of BA produced callus, but failed to produce shoots, although some explants developed roots (data not shown). Our results differ from that reported by Cousineau and Donnelly (1991) who did not pretreat 'Comet' red raspberry stock material with TDZ, but added TDZ to their regeneration medium and found no difference in adventitious shoot regeneration efficiency among leaf blade explants, detached petioles, and leaf explants with petioles attached. We observed that shoots grew from either or both of two cut ends of petioles and very seldom from the center, resulting in fewer shoots per petri dish. In our experiments, 3-week-old plantlets produced thin $(\approx 1 \mathrm{~mm}$ thick $)$ and short $(\approx 0.5 \mathrm{~cm}$ long) petioles, which usually made it impossible for them to be cut into sections. In contrast, shoots emerged from the cut surface at the base of the leaf blades and from the surface of the leaf blade, resulting in more shoots per explant for leaf explants.

Effect of cytokinin type on shoot organogenesis. In our research, BA $(5 \mu \mathrm{M})$ combined with $0.5 \mu \mathrm{M}$ IBA was found to be significantly more effective in inducing shoot regeneration than either kinetin or zeatin, at similar concentrations when shoot cultures were pretreated with TDZ (Fig. 2, A and B). BA and TDZ are the most commonly used cytokinins for regeneration of Rubus genotypes (Cousineau and Donnelly, 1991; Fiola and Swartz, 1986; Fiola et al., 1990; Gingas and Stokes, 1993; Graham and McNicol, 1990; McNicol and Graham, 1990). The effect of zeatin on organogenesis appears to be less efficient than TDZ in raspberry, blackberry, and hybrid cultivars (Graham et al. 1997).

Effect of auxin type on shoot organogenesis. We found that, when combined with $5 \mu \mathrm{m} \mathrm{BA}$, $0.5 \mu \mathrm{M} \mathrm{IBA}$ was significantly better than similar concentrations of IAA, NAA, or 2,4-D for shoot regeneration of 'Marion' blackberry (Fig. 2 C and D). The auxins 2,4-D and IBA are commonly used in Rubus regeneration protocols. Fiola and Swartz (1986) reported that 2,4-D level at $1.0 \mathrm{mg} \cdot \mathrm{L}^{-1}$ was ideal for promoting somatic embryogenesis from mature and immature red raspberry ovules. Graham et al. (1997) reported that NAA was the most effective auxin for initiating somatic embryogenesis in a wide range of Rubus genotypes.

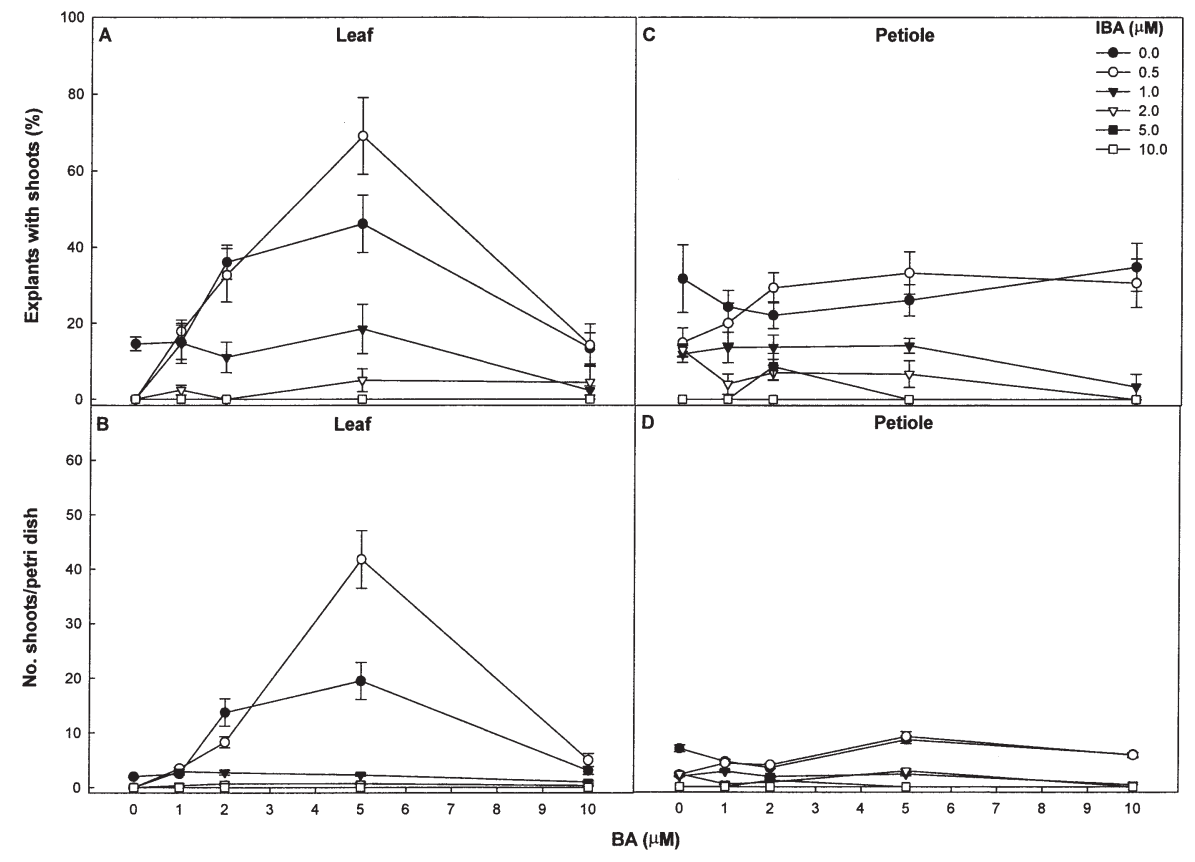

Fig. 1. Effect of BA and IBA concentration on shoot regeneration rate (\%) and number of shoots per petri dish for leaf (A and $\mathbf{B}$, respectively) and petiole ( $\mathbf{C}$ and $\mathbf{D}$, respectively). Vertical bars, which represent standard error, that overlap are not significantly different.

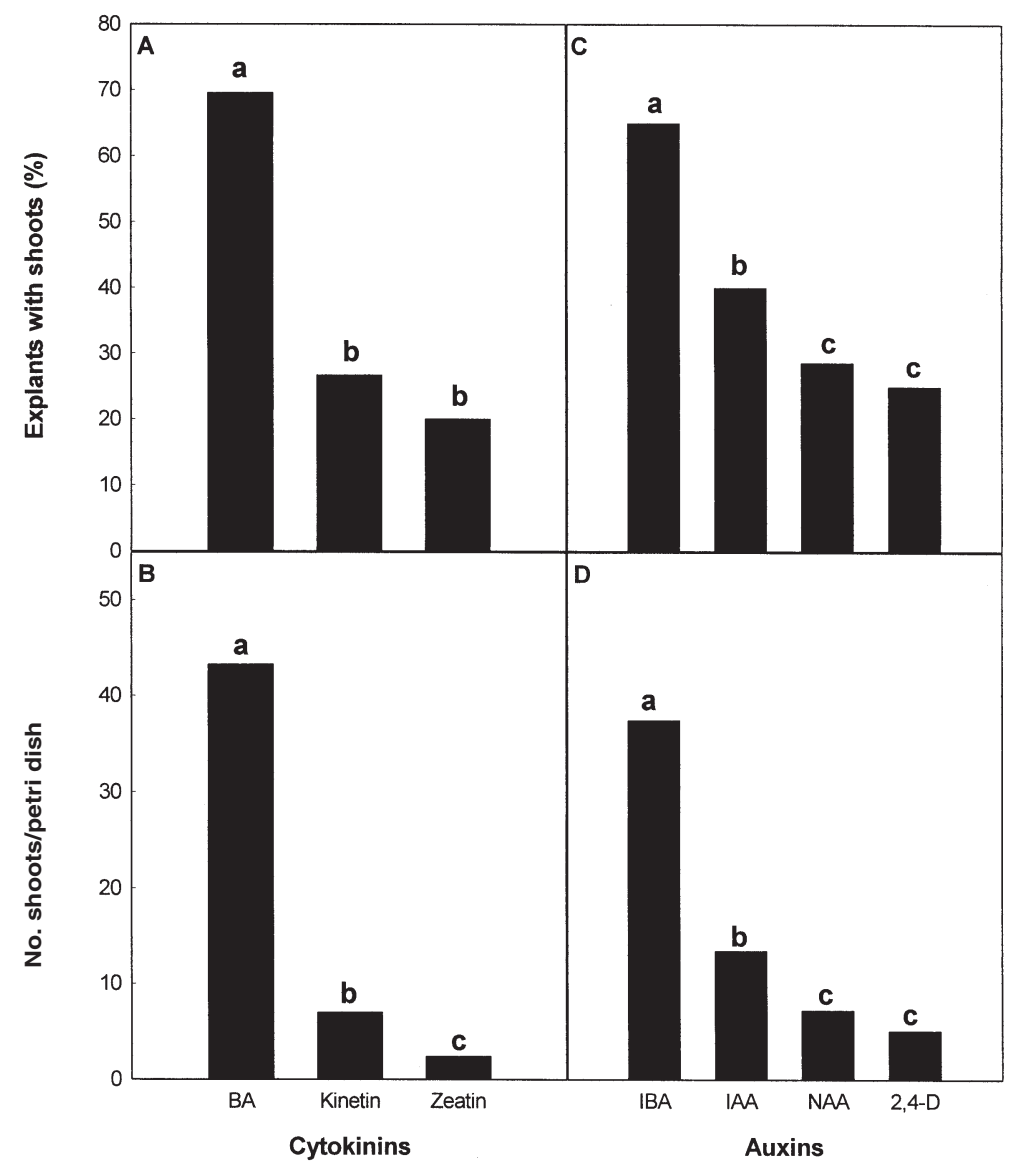

Fig. 2. Effect of $5 \mu \mathrm{M}$ cytokinins (BA, kinetin, and zeatin) or $0.5 \mu \mathrm{M}$ auxins (IBA, IAA, NAA, and 2,4-D) on shoot regeneration. (A) explants with shoots (\%) and (B) number of shoots per petri dish when IBA $(0.5 \mu \mathrm{M})$ was combined with each cytokinin separately. $(\mathbf{C})$ explants with shoots $(\%)$ and (D) number of shoots per petri dish when BA $(5 \mu \mathrm{M})$ was combined with each auxin separately. Bars with same letters are not significantly different according to least significant difference, $P \leq 0.05$ 
Effect of medium type on shoot organogenesis. Medium formulation affects regeneration efficiency for Rubus genotypes (Turk et al., 1994). While MS medium is used for a wide range of plant species, including Rubus, BMM was developed specifically for blackberry (Reed, 1990), and WPM, which was developed for Ericaceous plants, has also been used for some non-Ericaceous fruit crops (Zimmerman and Swartz, 1994). We found that regeneration percentage and the number of shoots per petri dish were significantly better on WPM medium than BMM or MS medium (Fig. 3, $\mathrm{A}$ and $\mathrm{B}$ ).

Effect of TDZ pretreatment on shoot regeneration. 'Marion' explants were unable to regenerate shoots without TDZ pretreatment under our conditions (Fig. 4, A and B). The regeneration percentage was significantly improved when a 3 -week TDZ pretreatment was used. However, the regeneration percentage declined when longer pretreatments were used (Fig. 4A). The number of shoots per petri dish was reduced when explants were taken from shoots pretreated 4 weeks or longer. When testing the effect of the length of time in the pretreatment, we found following polynomial formula: Regeneration efficiency $(\%)=36.41 *$ Week $-5.76 *$ Week $^{2}$ $\left(R^{2}=0.80, P<0.0001\right)$ and No. shoots/petri dish $=22.82 *$ Week $-3.88 *$ Week $^{2}\left(R^{2}=0.77\right.$, $P<0.0001)$. Although TDZ is a very effective cytokinin for many woody plant species, Tsao (1999) found that BA was better than TDZ for inducing shoots when it was included in the pretreatment and regeneration medium for a number of blackberry genotypes, including 'Marion'. However, TDZ induced shoot formation in other Rubus species when added directly to regeneration medium (Hassan et al., 1993; Turk et al., 1994) and when pretreating stock plants (Swartz et al., 1990; Tsao 1999). Swartz et al. (1990) reported that TDZ concentrations $>1 \mu \mathrm{M}$ excessively inhibited leaf size and their ability to be manipulated in vitro. We also observed that TDZ concentrations $>1 \mu \mathrm{M}$ stimulated hyperhydricity. Hence, we selected $1 \mu \mathrm{M} \mathrm{TDZ}$ for optimizing stock plant pretreatment conditions. Although hyperhydricity and abnormal leaves were found in all stock plants with various durations of TDZ pretreatment, prolonged TDZ treatment significantly increased the frequency of abnormalities.

Effect of leafintegrity on shoot organogen- esis. Whole leaves and the basal parts of the leaf explants were equally competent in shoot regeneration(Fig. 5). However, the distal part of the leaf explants failed to produce shoots. While Tsao (1999) found whole leaves were better than cut leaves, in our experiment there was no advantage to cutting leaf explants transversely as they did not produce more shoots than the intact leaf explants. Shoots did not form on the cut surface despite a significant amount of callus formation but were commonly observed at, and around, the cut surface at the base of the leaf blade (Data not shown).

Effect of leaf explant orientation on shoot organogenesis. It was reported that Rubus leaves responded similarly regardless of which epidermal layer was in contact with the medium surface (Mathews et al., 1995; Turk, et al., 1994). However, we found that regeneration percentage was higher and there were more shoots per petri dish when the abaxial side of the leaf was in contact with the medium $(64.3 \% \pm 8.9 \%$ and $35.5 \pm 27$ shoots/petri dish vs. $40.4 \% \pm 11.5 \%$ and 13.5 \pm 2.0 shoots/petri dish). Regardless of their orientation, all shoots were regenerated from the adaxial side of leaf explants.

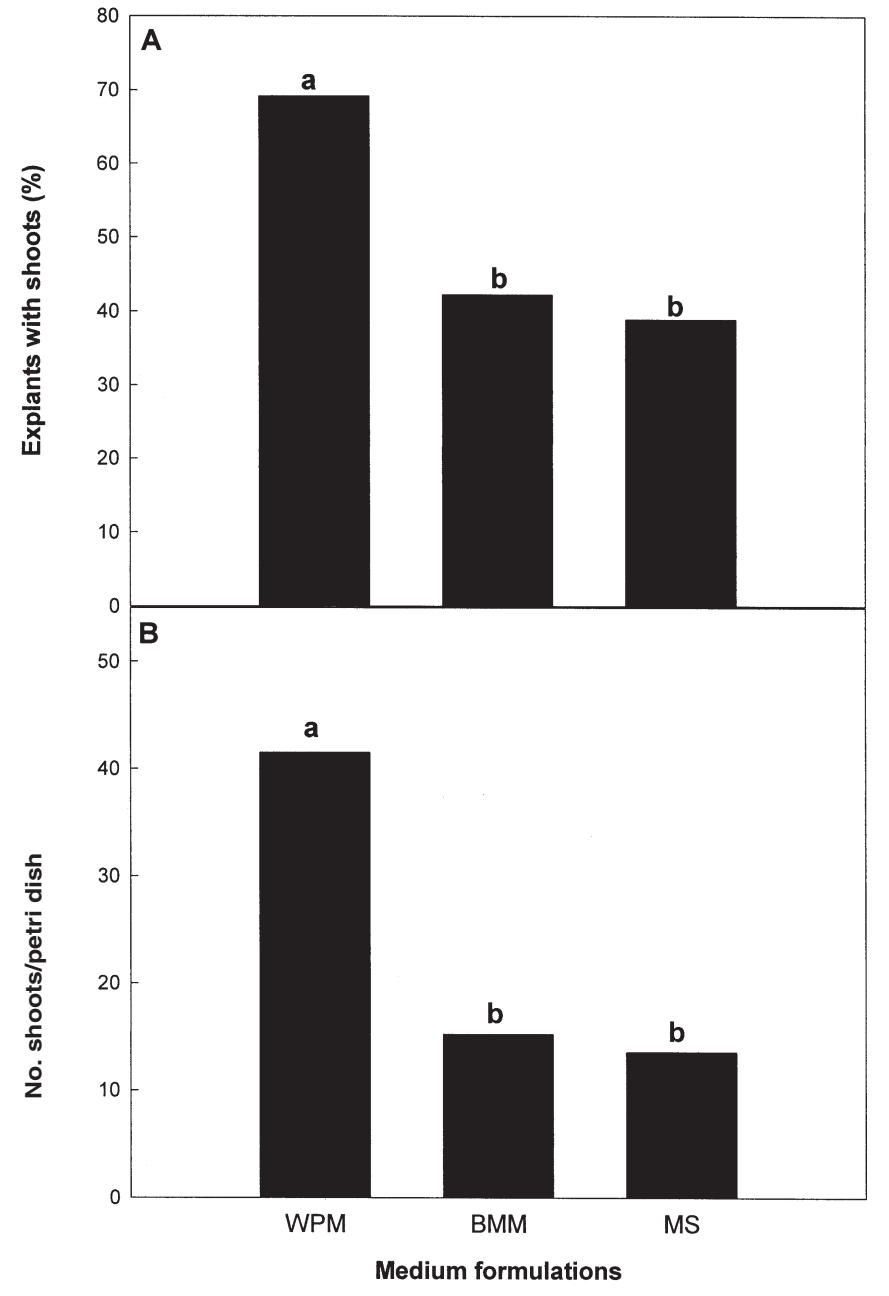

Fig. 3. Effect of medium salts formulation [Woody Plant Medium (Lloyd and McCown, 1980), Blackberry Multiplication Medium (Reed, 1990), and MS salts and vitamins (Murashige \& Skoog, 1962)] on the (A) explants with shoots (\%) and (B) number of shoots per petri dish. Bars with same letters are not significantly different according to least significant difference, $P \leq 0.05$.

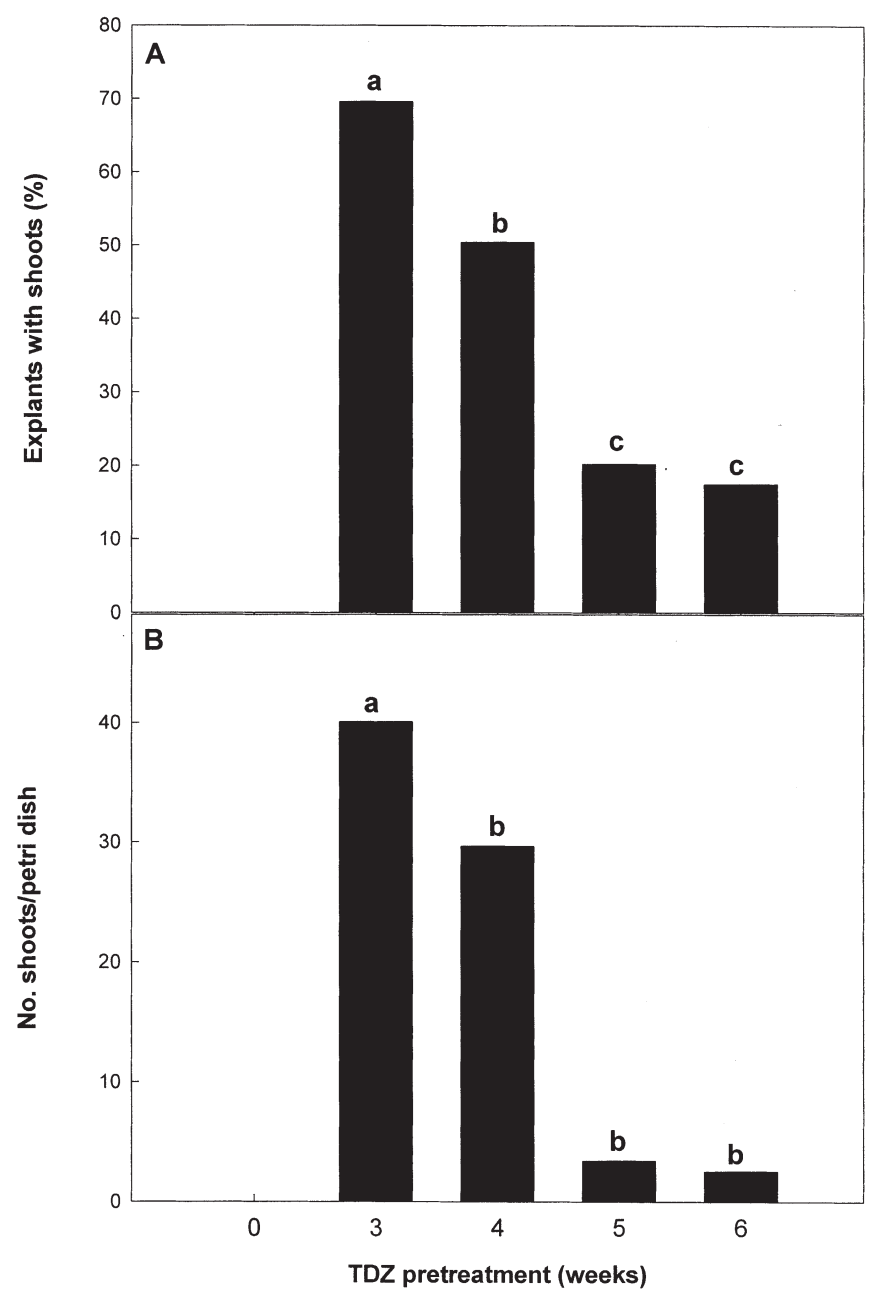

Fig. 4. Effect of 0, 3, 4, 5, and 6 weeks of TDZ pretreatments on (A) explants with shoots (\%) and (B) number of shoots per petri dish. Bars with same letters are not significantly different according to least significant difference, $P \leq 0.05$. 


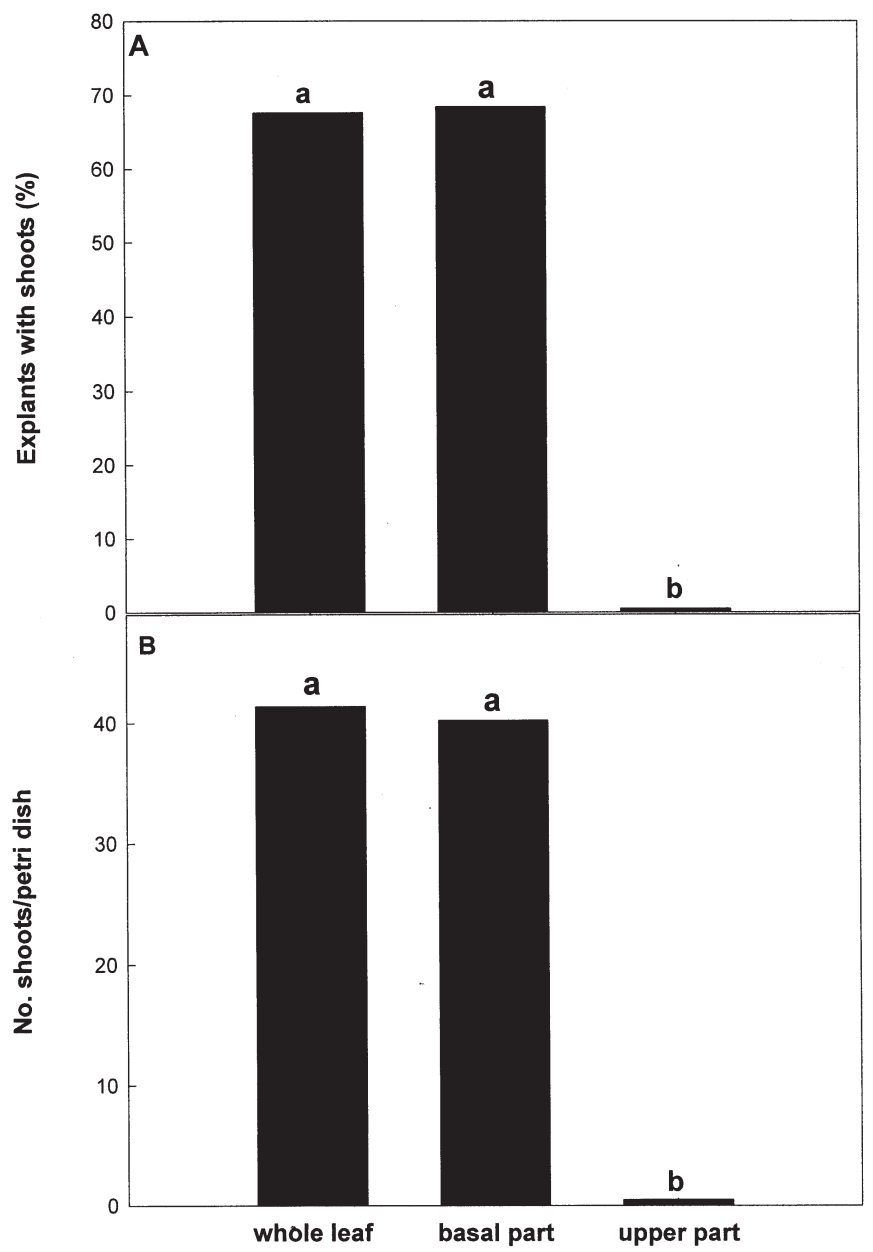

Fig. 5. Effect of leaf integrity on (A) explants with shoots (\%) and (B) number of shoots per petri dish. Bars with similar letters are not significantly different according to least significant difference, $P \leq 0.05$.

All the parameters we examined had significant effects on in vitro shoot regeneration of 'Marion'. Our results confirmed those reported by Tsao (1999) that TDZ pretreatment and high concentration of $\mathrm{BA}$, in combination with low concentration of IBA, induced shoot regeneration of 'Marion'. By optimizing all parameters described above, we were able to improve the regeneration efficiency to $\approx 70 \%$ compared to that reported previously $(\approx 40 \%)$. We are currently applying this improved in vitro plant regeneration system toward the development of a transformation protocol for 'Marion'.

\section{Literature Cited}

Anderson,W.C. 1975. Propagation of rhododendrons by tissue culture, Part 1. Development of a culture medium for multiplication of shoots. Proc. Inter. Plant Prop. Soc. 25:129-135.

Bell, N., E. Nelson, B. Strik, and L. Martin. 1992. Assessment of winter injury to berry crops in Oregon. 1991. Agr. Sta. Spec. Rpt. 902, Oregon State Univ.

Bell, N.C., B.C. Strik, and L.W. Martin. 1995. Effect of primocane suppression date on 'Marion' trailing blackberry II. Cold hardiness. J. Am. Soc. Hort. Sci. 120:25-27.

Chu, C.C., C.C. Wang, C.S. Sun, C. Hsu, K.C. Yin, and C.Y. Chu. 1975. Establishment of an efficient medium for anther culture of rice through comparative experiments on the nitrogen sources. Sci. Sin. 18:659-668.

Cortell, J.M. and B.C. Strik. 1997. Effect of floricane number in 'Marion' trailing blackberry. I. Primocane growth and cold hardiness. J. Am. Soc. Hort. Sci. 122:604-610.

Cousineau, J.C. and D.J. Donnelly. 1991. Adventitious shoot regeneration from leaf explants of tissue cultured and greenhouse-grown raspberry. Plant Cell Tis. Org. Cult. 27:249-255.

Finn, C., B.C. Strik, and F.J.Lawrence. 1997. 'Marion' trailing blackberry. Fruit Var. J. 51:130-132.

Fiola, J.A., M.A. Hassan, H.J. Swartz, and R. McNicols. 1990. Effect of thidiazuron, light fluence rates and kanamycin on in vitro shoot organogenesis from excised Rubus cotyledons and leaves. Plant Cell Tis. Org. Cult. 20:223-228.

Fiola, J.A. and H.J. Swartz. 1986. Somatic embryogenesis, organogenesis and proliferation in vitro from Rubus embryos. Acta. Hort. 183:91-98.

Graham, J. and R.J. McNicol. 1990. Plantlet regeneration and genetic transformation in soft fruit species. Acta Hort. 280:517-522.

Graham, J., L. Iasi, and S. Millam. 1997. Genotype-specific regeneration from a number of Rubus cultivars. Plant Cell Tis. Org. Cult. 48:167-173.

Hassan, M.A., H.J. Swartz, G. Inamine, and P. Mullineaux. 1993. Agrobacterium tumefaciens- mediated transformation of several Rubus genotypes and recovery of transformed plants. Plant Cell Tis. Org. Cult. 33:9-17.

Hall, H.K., M.H. Quazi, and R.M. Skirvin. 1986. Isolation of a pure Thornless Loganberry by meristem tip culture. Euphytica. 35:1039-1044.

Hoepfner, A.S., R. Nestby, and H. Nybom. 1996. Genetic deviation initiated by adventitious shoot regeneration from tissue cultured red raspberry. J. Hort. Sci. 71:71-79.

Jaglo-Ottosen, K.R., S.J. Gilmore, D.G. Zarka, O. Schabenberger, and M.F. Thomashow. 1998. Arabidopsis CBF1 overexpression induces COR genes and enhances freezing tolerance. Science 280:104-106.

Kasuga, M., Q. Liu, S. Miura, K. Yamaguchi-Shinozaki, and K. Shinozaki. 1999. Improving plant drought, salt and freezing tolerance by gene transfer of a single stress-inducible transcription factor. Nature Biotech. 17:287-291.

Lloyd, G. and B.H. McCown. 1980. Commerciallyfeasible micropropagation of mountain laurel, Kalmia latifolia, by use of shoot-tip culture. Proc. Intl. Plant Prop. Soc. 30:421-427.

Mathews, H., W.C. Wagoner, C. Cohen, and R. Bestwick. 1995. Efficient genetic transformation of red raspberry, Rubus idaeus L. Plant Cell Rep. 14:471-476.

Mezzetti, B., G. Savini, F. Carnevali, and D. Mott. 1997. Plant genotype and growth regulators interaction affecting in vitro morphogenesis of blackberry and raspberry. Biol. Plant. 39:139-150

McNicol, R.J. and J. Graham. 1990. In vitro regeneration of Rubus from leaf and stem segments. Plant Cell Tis. Org. Cult. 21:45-50.

Murashige T. and F. Skoog. 1962. A revised medium for rapid growth and bioassay with tobacco tissue cultures. Physiol. Plant. 15:473-479.

Pierik, R.L.M. 1987. Vegetative propagation. p. 183-230. In: Pierik, R.L.M. (ed.). In vitro culture of higher plants. Maritus Nijhoff Publishers, Dordrecht/Boston/Lancaster.

Reed, B.M. 1990. Multiplication of Rubus germplasm in vitro: A screen of 256 accessions. Fruit Varieties J. 44:141-148.

Sakamoto, A., R. Valverde, Alia., T.H.H. Chen, and N. Murata. 2000. Transformation of Arabidopsis with the $\operatorname{codA}$ gene for choline oxidase enhances freezing tolerance of plants. Plant J. 22 (5):449-453.

Strik, B.C. 1992. Blackberry cultivars and production trends in the Pacific Northwest. Fruit Var. J. 46:202-206.

Swartz, H.J., R. Bors, F. Mohamed, and S.K. Naess. 1990. The effect of in vitro pretreatments on subsequent organogenesis from excised Rubus and Malus leaves. Plant Cell Tis. Org. Cult. 21:179-184.

Tsao, C.W.V. 1999. Rubus leaf regeneration and micropropagation of virus infected raspberry. Ore. State Univ. MS Thesis.

Tsao, C.W.V. and B.M. Reed. 2002. Gelling agents, silver nitrate, and sequestrene iron influence adventitious shoot and callus production from Rubus leaves. In Vitro Cell. \& Dev. Biol.- Plant 38:29-32.

Turk, B.A., H.J. Swartz, and R.H. Zimmerman. 1994. Adventitious shoot regeneration from in vitro-cultured leaves of Rubus genotypes. Plant Cell Tis. Org. Cult. 38:11-17.

Zimmerman, R. and H. Swartz. 1994. In vitro culture for temperate fruits, p. 457-474. In: I.K. Vasil and T.A. Thorpe (eds.). Plant cell and tissue culture. Kluwer Academic, Boston. 